\title{
Advancing Our Understanding of Woody Debris in Tropical Forests
}

\author{
Christian P. Giardina* \\ Institute of Pacific Islands Forestry, USDA Forest Service, 60 Nowelo Street, Hilo, Hawaii 96720, USA
}

Fine and coarse woody debris (WD), or woody necromass, serves a multitude of functions in forests including: essential habitat for countless vertebrate, arthropod and microbial species; substrate for regenerating plants, for example as nurse logs; a dominant carbon source for heterotrophs; and both a sink and source for essential nutrients (Harmon and others 1986; Palace and others 2012). Further, as WD decomposes, resulting fragments and microbial by-products of the decay process provide a major source of organic matter for soils (Magnússon and others 2016). Finally, WD can account for up to $20 \%$ of carbon storage in forests (Harmon and others 1986; Palace and others 2012), with an important role in biosphere-atmosphere $\mathrm{CO}_{2}$ exchange.

Severe wind events, fires, insects and disease, and many types of management can result in the production of woody debris (Harmon and others 1986; Keller and others 2004; Palace and others 2012). The diverse forms that WD can take in a forest include logs on the ground, standing dead trees (snags), fragmented debris on the ground or incorporated into soil, and suspended dead stems or branches above the ground. The distribution of WD across these categories is controlled by: (i) the type of disturbance that killed the previously alive tree part, whole tree or even whole forest; (ii) time since disturbance because WD will physically move

Published online 25 April 2019

*Corresponding author; e-mail: cgiardina@fs.fed.us or change condition over time, for example snags becoming down logs becoming woody fragments; (iii) the size of the WD piece; and (iv) WD decay rates (Harmon and others 1986). The first three drivers are technically straightforward to observe, but because WD is so variable spatially and because changes often occur over such long time spans, making the required observations are logistically very intensive (Palace and others 2012). Not surprisingly, there are few comprehensive, large-scale and long-term studies of WD dynamics in forests, with remarkably few from the tropics. Decay processes, the fourth driver, are more complex, more cryptic, and so more difficult to observe; as a result, studies of WD decomposition are technically and logistically more challenging and so even less common.

What are the dominant decay processes for WD? Over time, a piece of WD will disappear from a forests as a result of leaching, fragmentation (also called comminution), transport, collapse and settling, heterotrophic conversion to $\mathrm{CO}_{2}$, and biological transformation into the microbial byproducts of decay (Harmon and others 1986). Rates for these processes are in turn driven by climate, including temperature and moisture, wood quality including cell wall chemistry of sapwood and heartwood, the density and anatomical structure of wood, size of the decaying wood, diffusion of $\mathrm{O}_{2}$ into wood, the availability of nutrients and labile carbohydrates, and the decomposers (bacteria, fungi, invertebrates and in some cases vertebrates) present on and in the wood (Barbosa and others 2017; Chao and others 2008; González and Luce 
2013; Harmon and others 1986; Iwashita and others 2013; Keller and others 2004; Magnússon and others 2016; Palace and others 2012; Yang and others 2010). Because the factors that drive WD formation, transformation, and loss from ecosystems are spatially and temporally very heterogeneous, it is not surprising that the distribution, abundance, and dynamics of WD are also very heterogeneous.

To date, studies of WD, including WD distribution, abundance, and dynamics, have focused primarily on snapshots of downed wood and snags, with most research being conducted in temperate forests. Smaller diameter WD, sometimes called fine woody debris and often originating as dead branches or the broken tops of trees, can represent a large portion of the WD budget, but quantitative studies of this WD source are few, prompting Palace and others (2012) to call for more study of this portion of the forest carbon cycle. Three tropical studies in this issue (Law and others 2019; Gora and others 2019a, b) break new ground by examining total WD amount, distribution, and dynamics, with a focus on underlying drivers of decay for fine WD in the understudied tropics. These innovative studies examine suspended WD in lowland rainforests of Malaysia and lowland moist forests of Panama in order to address important questions about the controls on suspended necromass dynamics, including the spatial variation in this material across a forest, and the drivers of its decay. These papers delve deeply into the biotic and abiotic mechanisms underlying measured decay rates and show important but not surprising vertical stratification of the abiotic factors that control decomposition. More surprising is the complex, height-driven interactions among climate, microbes, and invertebrates.

Gora and others (2019a) inventoried a mature moist tropical forest for WD, distinguished and tracked standing, downed, and suspended WD for 8 years, thereby resolving with unprecedented detail the dynamics of a tropical forest's WD budget. Building on work of Přívětivý and others (2016), Gora and others (2019a) show that ca. $50 \%$ of woody necromass is separated from the forest floor, where the process of decomposition has rarely been studied; their results show decomposition of suspended WD proceeds much more slowly than WD that is in contact with the forest floor. Law and others (2019) and Gora and others (2019b) monitored the decay of standardized wood samples (pine blocks in Malaysia, birch sticks in Panama), securely placed on trees along vertical transects from ground level to the forest canopy, to understand abiotic and biotic controls on spatial patterns of suspended WD decomposition. Law and others (2019) examined the role of temperature, moisture, termites, and microbes in wood block decay. Gora and others (2019b) examined climate and microbial community composition effects on the decay of birch sticks across soil to canopy gradients. Whereas Law and others (2019) relied on paired mesh-enclosed and open blocks to explicitly test the role of termites in the decay process, Gora and others (2019a) used mesh-enclosed sticks to isolate abiotic and microbial drivers of decomposition.

Law and others (2019) report a strong interaction between termites and microclimate, with very large differences between open and termite excluded blocks (much higher mass loss when termites were able to access the wood), but differences and overall rates declined with distance from the ground. Gora and others (2019b) also found strong negative effects of sample height on mass loss; as with the Law and others (2019) study, by far the largest changes occurred when moving from the ground to just off the soil surface. In line with previous WD findings in the tropics (Chambers and others 2000; Iwashita and others 2013), temperature was associated with WD dynamics in Panama and Malaysia; however, in both wood substrate studies, contact with soil and increased wood moisture exerted dominant influences on decay rates. Notably, Law and others (2019) report that the much larger influence of termites on wood decay is dependent on the distance of the wood source from the ground, with termite-driven decomposition in ground-based wood giving way to microbially driven decomposition in the canopy. Within the microbial community, Gora and others (2019b) found that turnover of fungal and bacterial communities covaried from the ground to the canopy, with communities and decomposition rates strongly associated with microclimate.

These studies highlight the importance of fine scale climate, microbial diversity, and termite abundance gradients, and the sensitivity of decomposition processes to their interactions across a forest. There are important lessons here for future work, with implications for how WD processes are captured within global carbon models. Tropical forests are typically highly diverse with respect to tree species composition within stands and diversity across forests, which means that WD inputs can be highly heterogeneous locally and across regions. Wood chemistry, anatomy, sample size, and nutrient content all affect decay rates and play a role in what organisms are able to colonize a given substrate. As a result of species-specific wood 
quality variation, turnover times for WD can range widely-for example from just over a year for a 30$\mathrm{cm}$-diameter Bursera simaruba log, to over a century for a 30-cm Manilkara zapota log (Harmon and others 1995). These decomposition differences have been known for millennia, as evidenced by 800-year-old wood lintels made from Manilkara zapota, still intact, in the exposed door ways of ancient Mayan archeological sites. Next-generation studies will need to rely on a greater diversity of substrate types and sizes to gain a more complete understanding of how abiotic and biotic factors interact to regulate WD decay. For now, while the common wood substrate methods used by Law and others (2019) and Gora and others (2019a, b) cannot be used to address all drivers of variation, they lay an important foundation for improving our understanding of the complexities of decomposition in tropical forest environments.

\section{REFERENCES}

Barbosa RI, Volkmer de Castilho V, Perdiz RO, Damasco G, Rodrigues R, Fearnside FM. 2017. Decomposition rates of coarse woody debris in undisturbed Amazonian seasonally flooded and unflooded forests in the Rio Negro-Rio Branco Basin in Roraima, Brazil. Forest Ecol Manag 397:1-9.

Chambers JQ, Higuchi N, Schimel JP, Ferreira LV, Melack JM. 2000. Decomposition and carbon cycling of dead trees in tropical forests of the central Amazon. Oecologia 122:380-8.

Chao KJ, Phillips OL, Baker TR. 2008. Wood density and stocks of coarse woody debris in a northwestern Amazonian landscape. Can J For Res 38:795-805.

González G, Luce MM. 2013. Woody debris characterization along an elevation gradient in northeastern Puerto Rico. Ecol Bull 54:181-93.

Gora EM, Kneale RC, Larjavaara M, Muller-Landau HC. 2019a. Dead wood necromass in a moist tropical forest: stocks, fluxes, and spatiotemporal variability. Ecosystems. https://doi.org/10. 1007/s10021-019-00341-5.
Gora EM, Lucas JM, Yanoviak SP. 2019b. Microbial composition and wood decomposition rates vary with microclimate from the ground to the canopy in a tropical forest. Ecosystems. https://doi.org/10.1007/s10021-019-00359-9.

Harmon ME, Whigham DF, Sexton J, Olmsted I. 1995. Decomposition and mass of woody detritus in the dry tropical forests of the northeastern Yucatan peninsula, Mexico. Biotropica 27:305-16.

Harmon ME, Franklin JF, Swanson FJ, Sollins P, Gregory SV, Lattin JD, Anderson NH, Cline SP, Aumen NG, Sedell JR, Lienkaemper GW, Cromack K Jr, Cummins KW. 1986. Ecology of coarse woody debris in temperate ecosystems. Adv Ecol Res 15:133-302.

Iwashita DK, Litton CM, Giardina CP. 2013. Coarse woody debris carbon storage across a mean annual temperature gradient in tropical montane wet forest. Forest Ecol Manag 291:336-43.

Keller M, Palace M, Asner GP, Pereira R, Silva JNM. 2004. Coarse woody debris in undisturbed and logged forests in the eastern Brazilian Amazon. Global Change Biol 10:784-95

Law S, Eggleton P, Griffiths H, Ashton L, Parr C. 2019. Suspended dead wood decomposes slowly in the tropics, with microbial decay greater than termite decay. Ecosystems. http s://doi.org/10.1007/s10021-018-0331-4.

Magnússon RÍ, Tietema AJ, Cornelissen HC, Hefting MM, Kalbitz K. 2016. Tamm review: sequestration of carbon from coarse woody debris in forest soils. Forest Ecol Manag 377:115.

Palace M, Keller M, Hurtt G, Frolking S. 2012. A review of above ground necromass in tropical forests. In: Sudarshana $\mathrm{P}, \mathrm{Na}-$ geswara-Rao M, Soneji JR, Eds. Tropical forests. Intech (online publisher). pp 215-52. Published online at http://www. intechopen.com/books/tropical-forests.

Přívětivý T, Janík D, Unar P, Adam D, Král K, Vrška K. 2016. How do environmental conditions affect the deadwood decomposition of European beech (Fagus sylvatica L.)? Forest Ecol Manag 381:177-87.

Yang FF, Li YL, Guo YZ, Wenigmann KO, Zhang DQ, Wenigmann M, Liu SZ, Zhang QM. 2010. Dynamics of coarse woody debris and decomposition rates in an old-growth forest in lower tropical China. Forest Ecol Manag 259:1666-72. 